\title{
Analysis on Spontaneous Combustion of the Jurassic Coal Based on Low-temperature Oxidation
}

\author{
Gen-Yin $\mathrm{CHENG}^{1,2, \mathrm{a}}$, Shan FENG ${ }^{2}$, Zhen-Lei NIU ${ }^{2, \mathrm{~b},{ }^{*}}$, YI-Fei ZHOU ${ }^{2}$ \\ ${ }^{1}$ Department of Safety Training of North China Institute of Science and Technology, Sanhe, Hebei \\ 065201, China \\ ${ }^{2}$ College of Safety Engineering North China Institute of Science and Technology, Sanhe, Hebei \\ 065201,China \\ agycheng@ncist.edu.cn, ${ }^{\mathrm{b}} 446125529 @ q q . c o m$
}

Key words: Jurassic coal; spontaneous combustion; low-temperature oxidation; Northwest China

\begin{abstract}
The Jurassic coal of NW China has huge recoverable reserves but large spontaneous combustion tendency. Studying on spontaneous combustion mechanism of Jurassic coal is behind of the East and north of the Carboniferous Permian. Therefore, understanding the status of fire prevention of Jurassic seam of Northwest Region is of great significance to establish research orientation of spontaneous combustion of Northwest Jurassic mines and develop the theoretical system of spontaneous combustion. The paper summarizes Jurassic coal rock features of NW China, describes in detail its low temperature oxidation characteristics of spontaneous combustion and promotes the existing spontaneous combustion model to the Jurassic coal seams. In the end, further research on laboratory studies, numerical simulation and field practice of the Jurassic coal is recommended.
\end{abstract}

\section{Introduction}

Low and Middle Jurassic is an important period of coal accumulating in Chinese history. Its reserves of about $68.7 \%$ of total coal reserves and it distributes in the northwest, Middle South, East and other regions, the most important of which is Northwest China [1]. According to the forecast data of the third national coal field, the coal resources of Jurassic in the NW accounts for 39.6\% of the total amount of coal resources in the coal age of China [2]. The Jurassic coal with excellent quality from NW China accounts for $90 \%$ of China's low ash, low sulfur, and low phosphorus coal resources [3].

More than half of the coal seam belongs to the coal seam of spontaneous combustion in China, and the Jurassic coal seam spontaneous combustion in the northwest is particularly serious, involving more than 80 coal field and including Xinjiang coal burned 5.82 million coal resources every year and threatening reserves of 47.7 billion tons[4,5]. Spontaneous combustion of coal seam not only destroys a large number of high quality coal resources, threatens normal coal mining activities, and resulting harmful gases emissions into the atmosphere worsens the quality of regional environmental. Therefore, the prevention and control of the Jurassic coal seams in the northwest region is of great significance for the protection of the ecological environment, reducing the loss of resources and ensuring the safety of coal mining.

\section{Characteristics of Coal and Rock}

Organic Components of Coal. Characteristic of the northwest Jurassic coal is rich inertinite, the majority of which is more than $35 \%$, even as high as $60 \%$. The fusain used to gather into layer distribution, and macro lithotype is semi dull coal primarily. Secondly, the transitional components of coal and rock components (half vitrinite and half inertinite) are up to $10 \% \sim 20 \%$. Exinite generally is less than 3\% 5\%. Han Dexin thinks in the northwest Jurassic coal accumulation area of non-caking coal and weakly caking coal, inertinite often accounts for up to $40 \% \sim 50 \%$, and the ratio of vitrinite/inertinite often reaches 1 . High inertinite content causes that coal volatile reduces; 
cohesiveness goes bad, the hydrogen content decreases and the carbon content increases.

The inertinite of eastern Permo Carboniferous coal generally is around $20 \%$ and mainly is semi bright coal and bright coal with rare macroscopic fusain[6]. Refer to relevant literature, Table 1 can be obtained.

Table 1 Comparison of coal and rock components

\begin{tabular}{ccccc}
\hline Coal forming period & $\begin{array}{c}\text { Macroscopic } \\
\text { type }\end{array}$ & Mirror group & Inertinite goup & Exinite group \\
\cline { 3 - 5 } & Semi dark & $30 \% \sim 60 \%$ & $35 \% \sim 60 \%$ & $\begin{array}{c}\text { Less } \\
\text { than3\% 5\% }\end{array}$ \\
$\begin{array}{c}\text { Northwest Jurassic } \\
\text { dominated }\end{array}$ & aiyuan formation of \\
$\begin{array}{c}\text { Carboniferous } \\
\text { Permian Shanxi } \\
\text { formation }\end{array}$ & Semi bright type & $60 \% \sim 90 \%$ & Less than30\% & Less than15\% \\
\hline
\end{tabular}

Degree of Metamorphism of Coal. Northwest Jurassic coal ranges from lignite to anthracite. About $90 \%$ of the degree of metamorphism is in the low rank bituminous stage (long flame coal, non-caking coal, weak caking coal, $1 / 2$ caking coal); the resources amount of metamorphic bituminous coal (gas coal, fat coal, coking coal, lean coal) accounts for only $5.5 \%$ of the total amount; high rank coal (lean coal, anthracite) accounts for only $0.29 \%$. Bai Xiangfei thinks that the low degree of metamorphism and the degree of reduction of the Jurassic coal together determine the unique characteristics of the coal in the northwest region, the coal quality grades is given priority to non-caking coal and weakly caking coal[7].

Table 2 Degree of coal metamorphism in the northwest of China

\begin{tabular}{cccc}
\hline $\begin{array}{c}\text { Metamorphic } \\
\text { grade }\end{array}$ & $\begin{array}{c}\text { The low metamorphic } \\
\text { bituminous coal }\end{array}$ & $\begin{array}{c}\text { Medium metamorphic } \\
\text { bituminous coal }\end{array}$ & $\begin{array}{c}\text { High metamorphic } \\
\text { bituminous coal }\end{array}$ \\
\hline $\begin{array}{c}\text { Resource } \\
\text { accounting }\end{array}$ & About $90 \%$ & About $5.5 \%$ & About $0.29 \%$ \\
\hline
\end{tabular}

\section{Oxidation Characteristics during Coal Combustion Research}

The coal characteristics of spontaneous combustion are determined by oxidation and exothermicity together, so the laboratory research method with coal sample is feasible and reliable. Yang Yongliang[8] and Li Xiaqing[9] selected more than 4 groups of NE Jurassic coal in the experiment. But only Wang Kai and Cheng You studied the oxidation characteristics systematically about Jurassic coal samples in Northern Shaanxi and western Inner Mongolia. Wang Kai selected eight groups of Jurassic coal samples in northern Shaanxi (seven groups are weakly caking coal and one group is long flame coal) and three groups of Carboniferous-Permian coal samples (fat coal, lean coal and anthracite); Cheng You and Cheng Genyin selected 4 different western Inner Mongolia mining group Jurassic metamorphic grade coals and other 2 Group Carboniferous coals. The following conclusions are obtained through a series of experiments.

(1)Through the industrial analysis experiment of coal sample, we can know the Jurassic coal sample has the characteristics of high volatile and low ash content; we also know from the analysis of elements of the Jurassic coal, it has low carbon content and high oxygen content.

(2) Li Xiaqing, Cheng You and Cheng Genyin all used ZRJ-1 coal spontaneous combustion analyzer to measure the oxygen uptake of Jurassic coal samples. The results consistently show that Jurassic coal has higher oxygen uptake and stronger coal-oxygen compound effects in line with the real law of Jurassic coal liable to spontaneous combustion. With the experimental heating rate of the thermal analysis increases, characteristic temperature of coal samples increases and the rate of heat 
absorption also increase. Chen You thinks the absorbed heat of the coal samples at different heating rates are almost the same as the total heat absorbed in the absorption phase by DSC curve integral. In addition, Wang Kai also analyzes the effect of coal particle size on thermal analysis experimental results that, in general, the smaller the particle size, the greater the surface area, the lower the characteristic temperature.

(3)They used Fourier transform infrared spectroscopy to analyze Jurassic coal samples at different temperatures and describe qualitatively the changing characteristics of hydroxyl, aromatic hydrocarbons, aliphatic hydrocarbons and oxygen-containing functional groups according to the infrared absorption spectra and the absorption peak of active structure .

(4)The macroscopic characteristics of coal sample spontaneous combustion are analyzed by the temperature programmed experiments. From the experimental chart, it can be seen that the oxygen consumption rate, $\mathrm{CO}$ gas production rate and heat release rate during the Jurassic coal sample oxidation are higher than other coal samples, and the exponential relationship increases with the temperature.

\section{Numerical Simulation Study}

Air Leakage Field Equation. Airflow in the goaf can be regarded as seepage in porous media, consistent with Darcy's law, which will be applied to the fluid continuity equation. It is considered that the gas density is essentially the same in the goaf. The mass equation of air leakage in the goaf can be obtained.

$$
\frac{\partial}{\partial \mathrm{x}}\left(\mathrm{K}_{\mathrm{x}} \frac{\partial p}{\partial \mathrm{x}}\right)+\frac{\partial}{\partial \mathrm{y}}\left(\mathrm{K}_{\mathrm{y}} \frac{\partial p}{\partial \mathrm{y}}\right)+\frac{\partial}{\partial \mathrm{z}}\left(\mathrm{K}_{\mathrm{z}} \frac{\partial p}{\partial \mathrm{z}}\right)=0
$$

In the formula, $\mathrm{K}_{\mathrm{x}}, \mathrm{K}_{\mathrm{y}}, \mathrm{K}_{\mathrm{z}}$ - permeability coefficient; $\mathrm{p}$-air leakage pressure.

Oxygen Concentration Field. In the seepage process, oxygen occurs physical adsorption, chemical adsorption and coal-oxygen compounding effects. Along the seepage direction, oxygen concentration continues to reduce and form concentration gradient along the streamline in the goaf. Oxygen moves under the interaction of molecular diffusion and seepage. Oxygen molecular diffusion obeys Fick's law, while the oxygen group's the law of mass conservation is actually concentration of oxygen flow transfer equation, therefore oxygen concentration field in goaf can be expressed as follows.

$$
\frac{\partial \mathrm{c}}{\partial \tau}+\mathrm{u}_{\mathrm{x}} \frac{\partial \mathrm{c}}{\partial \mathrm{x}}+\mathrm{u}_{\mathrm{y}} \frac{\partial \mathrm{c}}{\partial \mathrm{y}}+\mathrm{u}_{\mathrm{z}} \frac{\partial c}{\partial \mathrm{z}}=D_{\mathrm{e}}\left(\frac{\partial^{2} c}{\partial \mathrm{x}^{2}}+\frac{\partial^{2} c}{\partial \mathrm{y}^{2}}+\frac{\partial^{2} c}{\partial \mathrm{z}^{2}}\right)-V(T)
$$

In the formula, $\mathrm{c}-$ Oxygen volume concentration; $\mathrm{D}_{\mathrm{e}}-$ oxygen diffusion coefficient in loose coal; $\mathrm{V}(\mathrm{T})$ —oxygen consumption rate of coal in goaf.

Temperature Field. Coal solid particle and pore gas must obey the first law of thermodynamics and the law of conservation of energy. Ignoring the thermal radiation effect of loose coal and simplifying the goaf conditions, temperature field equation can be written based on Fourier's law launched for goaf.

$$
\rho_{\mathrm{e}} \mathrm{c}_{\mathrm{e}} \frac{\partial T}{\partial \tau}=\mathrm{q}(T)+\lambda_{\mathrm{e}}\left(\frac{\partial^{2} T}{\partial \mathrm{x}^{2}}+\frac{\partial^{2} T}{\partial \mathrm{y}^{2}}+\frac{\partial^{2} T}{\partial \mathrm{z}^{2}}\right)-\rho_{g} \mathrm{c}_{g}\left(\mathrm{u}_{\mathrm{x}} \frac{\partial T}{\partial \mathrm{x}}+\mathrm{u}_{\mathrm{y}} \frac{\partial T}{\partial \mathrm{y}}+\mathrm{u}_{\mathrm{z}} \frac{\partial T}{\partial \mathrm{z}}\right)
$$

In the formula, g, e-gas and coal; $\lambda_{\mathrm{e}}$-thermal conductivity of loose coal; $q(\mathrm{~T})$ - exothermicity of float coal in goaf;

Numerical Simulation. Air leakage's flow field, the oxygen concentration field and the temperature field equation are derived based on Darcy's law, Fick's law, Fourier' law, the law of conservation of mass and the law of conservation of energy. So they can be applied in the Jurassic coal mining goaf's spontaneous combustion simulation. But in practice, it is necessary to determine 
the key parameters in the model through the program heating experiments or large natural ignition experiment, combined with theoretical analysis to, such as the diffusion coefficient of oxygen, oxygen consumption rate and heat release intensity etc.; at the same time the boundary conditions and initial conditions should be determined according to the specific simulation.

The simulation research on the law of spontaneous combustion in goaf of the Jurassic coal seam is rarely introduced. Deng Jun, Wen Hu and Zhang Xinhai established the high temperature combustion chemical reaction and physical model of coalfield fire area, set parameters according to the mathematical model and dynamically simulated the spontaneous combustion law of Wuda No. 8 coalfield of Jurassic coal. So, mature numerical simulation results extracted from the Carboniferous Permian can be applied to northwest Jurassic coal mining area, and further research northwest Jurassic coal mining goaf's characteristic of spontaneous combustion. In the end, the Jurassic coal mining goaf's spontaneous combustion rule can be summarized.

\section{Fire-Fighting Field Practice}

Since the 1950s, China's mine internal-caused fire prevention technology has made great development. There exist the fire extinguishing with mud, plugging and even pressure fire prevention and extinguishing technology, grouting fire prevention and extinguishing technology, inert gas fire extinguishing technology, the resistance of the fire prevention and extinguishing technique, gel and foam fire prevention and extinguishing technology. Mine fire prevention and control technology after nearly 60 years of development, has formed a fire comprehensive fire prevention and control technology, combining prediction, monitoring, prevention and treatment [10]. However, many fire prevention and extinguishing technology practice mainly comes from Carboniferous Permian coal mine, and fire prevention and extinguishing the practice of northwest Jurassic coal mine study are focused on the Jurassic coal field in Northern Shaanxi Province and Shenfu-Dongsheng coalfield[11,12].

Wu Yuguo deeply studied the CO generation and migration laws of fully mechanized coal face in Shendong mining area, and developed fire prevention and extinguishing technology management standards with the actual mine, which has a strong reference [13] to solve the northwest Jurassic coal mine CO overrun. Aiming at typical coal fire with "burning for a long time, wide range, large heat storage capacity, high temperature of coal and rock, complicated air leakage of cavities and fractures" characteristics and mechanism, coalfield fire prevention and control of innovation team of Xi⿳an University of Science and Technology developed the composite gel fire-fighting material, using loess and sand as main raw materials, invented ground mobile type multifunctional grouting and injecting system, and successfully controlled the Pingshuo Mine No.1 fire area and the Benla coalfield fire area in the Inner Mongolia, etc.

\section{Summary}

(1) Jurassic coal mainly distribute from lignite to anthracite distribution in the northwest region and give priority to non-stick coal and weakly caking coal. Compared to other coal samples forming different periods, the significant characteristics of Northwest Jurassic coal is rich in inertinite, the majority of which is more than $35 \%$, even up to about $60 \%$. The fusain often gathers in layers, the lithotype often is dominated by half semi dull coal; the exinite generally is less than $3 \% \sim 5 \%$.

(2) Jurassic coal low temperature oxidation and spontaneous combustion characteristics are introduced in detail. The physical and chemical structure and dynamics analysis, various features of functional groups and macro spontaneous combustion parameters show that Jurassic coal samples have more spontaneous combustion tendency than the coal samples forming other period. The oxidation rate and heat release rate of the Jurassic coal are high, which can provide reference for determining the key parameters in the numerical simulation.

The laboratory comparative studies on northwest Jurassic coal seam spontaneous combustion can select the same metamorphic grade of Jurassic and Carboniferous Permian coal sample, or Jurassic coal in different metamorphic degree of coal sample to provide more adequate theoretical basis 
for revealing the mechanism of Jurassic coal spontaneous combustion.

(3) At present, the northwest Jurassic coal's spontaneous combustion research is relatively concentrated in the Erdos basin, especially Northern Shaanxi Jurassic and Shenfu-Dongsheng area. Technical personnel should deeply study the characteristic of northwest Jurassic coal mining goaf's spontaneous combustion, and promote the application of Carboniferous Permian coal mines' mature spontaneous combustion mathematical model and lots of fire prevention and control technology, and summarize spontaneous combustion rule of Jurassic coal goaf and develop more practical new materials and equipments.

\section{Acknowledgment}

This research was financially supported by the National Natural Science Foundation (No. U1361130) and the Fundamental Research Funds for the Central Universities (No.3142015058).

\section{Reference}

[1] Han Dexin. Chinese coal petrology [M]. Beijing: China University of Mining and Technology press, 1996

[2] Mao Jiehua, Xu Huilong. Chinese coal resource distribution status and prospect of [J]. coal geology, 1999, 27:1-4.

[3] Li Xiaoyan, Jin Xianglan, Li Honggui. West China in the exploitation of coal resources, the concept of high-quality coal and use problems. Coal geology, 2005, 17 (3): 5-8.

[4] Tan Yongjie. Spontaneous combustion disaster and its prevention and control measures in China coal field [J]. coal field geology and exploration, 2000, 28 (6): 8-10.

[5] Deng Jun, Wen Hu, Zhang Xinhai, etc. the theory and technology of fire prevention and control [M]. Xuzhou: China University of Mining and Technology press, 2014

[6] Huang Wenhui, Tang Shuheng, Tang Xiuyi, etc. Study on the coal and rock characteristics of Jurassic coals in the northwest of China [J]. coal field geology and exploration, 2010,38 (4): 1-6.

[7] Bai Xiangfei, Li Wenhua, Chen Wenmin. Study on China's western coal weak reduction degree and coal distribution [J]. Journal of China coal society, 2005,30 (4): 502-506.

[8] Yang Yongliang. Test of the shortest spontaneous combustion period of coal and the technology of prevention and control of coal spontaneous combustion [D] Beijing: China University of Mining and Technology, 2009

[9] Li Xiaqing. Experimental study on the characteristics of low temperature oxygen absorption of coal [D] Xi'an: Xi'an University of Science and Technology, 2011

[10] Liang Yuntao, Luo Haizhu. Status and trends of fire prevention and control technology for coal mine in China [J]. Journal of coal science, 2008,33 (2): 126-130.

[11] Liu Yuanguang. Coal mining comprehensive fire prevention technology research on Yangchangwan coal mine [D] Xi'an: Xi'an University of Science and Technology, 2005

[12] Rui Guoxiang, Wang Yuhuai, Ren Jianjun, etc. Study and Application of Spontaneous Combustion Indicator Gas in No. 3 Coal Seam of Chahasu Coal Mine [J]. Journal of North China University of technology, 2015,12 (2): 20-24.

[13] Wu Yuguo. Study on generation and migration of CO from coal oxidation under ambient temperature in active goafs of fully mechanized longwall panels in Shendong mine district and its application [D]. Taiyuan: Taiyuan University of technology, 2015. 